\title{
Correction: Doing well by doing good with the performance of United Nations Global Compact Climate Change Champions
}

Moses Msiska, Alex Ng \& Randall K. Kimmel (1)

Correction to: Humanities and Social Sciences Communications https://doi.org/10.1057/s41599-021-00989-2, published online 10 December 2021.

In this article, the affiliation details for Alex Ng were incorrectly given as 'United International College, Zhuhai, China' but should have been 'BNU-HKBU United International College, Zhuhai, China'. The original article has been corrected.

Published online: 14 January 2022

\begin{abstract}
(c) (i) Open Access This article is licensed under a Creative Commons Attribution 4.0 International License, which permits use, sharing, adaptation, distribution and reproduction in any medium or format, as long as you give appropriate credit to the original author(s) and the source, provide a link to the Creative Commons license,

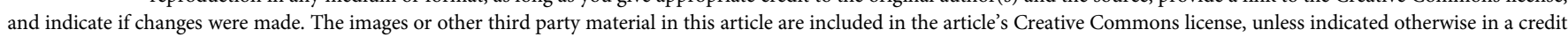
line to the material. If material is not included in the article's Creative Commons license and your intended use is not permitted by statutory regulation or exceeds the permitted use, you will need to obtain permission directly from the copyright holder. To view a copy of this license, visit http://creativecommons.org/licenses/by/4.0/.
\end{abstract}

(C) The Author(s) 2022 